\title{
IMPROVING STUDENTS VOCABULARY THROUGH BBC'S VIDEO IN INSTAGRAM AT JUNIOR HIGH SCHOOL
}

\author{
Kammer Tuahman Sipayung ${ }^{1 凶}$ \\ ${ }^{1}$ English Language Department, FKIP UHN, Perintis, Kec. Medan Tim., Kota Medan, Sumatera Utara, \\ 20232. \\ $凶_{e-m a i l}:$ Kammertuahmansipayung@gmail.com
}

\begin{abstract}
Vocabulary is a linguistics ellement of language skills. The purpose of this research is to describe the role of $B B C$ 's Video in Instagram for improving students' mastery on vocabulary. This research is a class room action research based on the theory of Kemmis and McTaggart (1988). The researcher used three times of classroom action cycle to achieve the goal. The population of this research is students at SMP Negeri 3 Medan and the sample is students at grade seven-two. The data of this classroom action research is score from each cycle. The result of this research shows us that $B B C$ 's Video in instagram as a media of teaching English is able to improve students' mastery on vocabulary. It can be seen in the first cycle their average score is 60.1, in the second cycle is 72.3 and the last cycle is 85.1. This result shows us that video in instagram is a good instrument to improve the students' mastery in vocabulary. It is suggested to other English teacher to make this media as an alternative media as far as the teaching method is supported to use.
\end{abstract}

Keywords: Instagram, Video, Vocabulary.

\begin{abstract}
Abstrak
Kosakata adalah suatu elemen linguistik dari keterampilan berbahasa. Tujuan dari penelitian ini untuk mendeskripsikan peran video BBC yang terdapat pada instagram untuk meningkatkan penguasaan kosakata terhadap siswa SMP. Penelitian ini ada penelitian tindakan kelas. Peneliti menerapkan cycle penelitian tindakan kelas tersebut untuk mencapai tujuan penelitian ini. Populasi dari penelitian ini adalah siswa SMP negeri 3 Medan dan sampel penelitian ini adalah siswa kelas tujuh-dua. Data penelitian ini adalah nilai kosakata dari setiap cycle. Hasil dari penelitian ini menunjukkan bahwa video BBC pada instagram yang digunakan sebagai media pengajaran bahasa Inggris mampu meningkatkan penguasaan kosakata terhadap siswa. Hal dapat terlihat dari nilai rata-rata pada cycle pertama adalah 60, pada cycle 2 adalah 72.3 dan cycle terakhir adalah 85.1. Hasil ini menunjukkan bahwa video BBC pada instagram adalah media yang baik untuk meningkatkan penguasaan kosakata. Disarankan untuk guru bahasa Inggris membuat media ini sebagai alternatif sejauh metode mengajar tersebut mendukung.
\end{abstract}

Kata Kunci: Instagram, Video, Kosakata.

\section{Introduction}

Work from home (WFH) is a high recomendation by Indonesian government since the out break of Pandemic Covid-19. In addition to that, Indonesian government suggest to keep social distance to avoid the virus of Covid-19. In this situation the role of teaching media really play a capital role. Stated that the important role for media in the delivery of instruction is in distance education (Pangaribuan, Sinaga, \& Sipayung, 2017).
This situation is affected to the process of teaching and learning at school. This effect lead to the shift of teaching system from face to face become online teaching and learning system. Nadiem Anwar Makarim (the minister of Education and Culture) states that all schools from lowest up to the highest level must study from home through online (Mozes, 2020). This situation force whole teachers to change their teaching method and media. 
Media could give a positive impact on the climate of teaching. Technology, as the newest instructional media developed in this globalization era, presents situation which helps the students to have new authentic and meaningful learning experiences engaging their effort and behavior by providing more fun and effective learning atmosphere (Fatimah \& Santiana, 2017). It is to indicate that media of teaching is a helper to the students to develope their mastery in learning language. The positive effect on pandemic situation to force whole theacher to use media platform in the virtual teaching.

However, most of teachers are lack on teaching by using social media. Their habit in face to face teaching or conventional teaching is difficult to move. In this case, most of them are familiar to use instagram. Instagram, like other social media channels, allows teaching and learning process with the topics outside the formal curriculum (Gulati \& al., 2020). It means that whole topics can be taught through instagram. In this case, the researcher used to teach vocabulary.

In addition to that the finding of stated that most students showed high positive perceptions in using Instagram in their learning since social network Instagram influenced their motivation, engangement, and attitudes (Sari, 2013). The reseacher needs to motivate the students in this pandemic covid 19. The researcher believes, through the students' high motivation and attitude. It affects to the positive result on students' vocabulary mastery. It is emphasized state that there was significant improvement of the students' vocabulary mastery that showed significant as 0.001 which is smaller than $\mathrm{a}=0.05$ through instagram (Kamal). Students were interested in learning English vocabulary through Instagram and categorized as
high.Students were interested because of these four major factors namely simplicity, accessibility, feeling of happiness, and students' vocabulary mastery achievement.Their findings lead the reseacher' interest to solve distance teaching at SMP Negeri 3 Medan. These are great reason to the researcher to make BBC's video in instagram become a media in teaching English.

Instagram is a good resource to support distance learning. Instagram consists a lot of content creator. In the other point of view, the English teachers need to be wise to choose the content. The content should be appropriate to the students' need. The content from the instagram should be based or suitable to Indonesian context. Instagram is categorized as a good alternative media and students can discuss relate to their teaching topic/activity. In other words, instagram is an effective media since the students can interact to each other.

This research have some previous study. investigate the affect of instagram on teaching recount (experiment study) (Sallamah, Husein, \& Sabiq, 2020). This research figure out that instagram significantly affects to the writing recount achievement. Conduct a similar research with classroom action research method (Sirait \& Marlina, 2018). They found that Instagram as an effective tool for developing learners' vocabulary range and grammatical accuracy. Conduct a similar research on teaching writing through instagram tool (Kemmis \& McTaggart, 1988). They stated that there are some advantages to use instagram as a tool or media in teaching descriptive writing. Some adventages are (1) it motivates students in writing, (2) it gives convenient and easy to use, (3) it needs less paper, (4) it is more flexible in time, (5) it allows for multimedia interaction, (6) students will take responsibility for their works. 
In this classroom action research, the researcher focuses on vocabulary. Based on the previous investigation and interview to some English teachers, they are difficult to teach English generally and especially on teachingvocabulary since the pandemic situation or in social distance. They are difficult to create a postive climate and lack of teaching medial platform for education.

Vocabulary is a fundamental requirement that influence students' achievement in studying English (Kamal). It is categorized as a fundamental since vocabulary is an element to support the language skills (speaking, reading, listening and writing).

Practically, the significances of this research are benefit for English teachers in teaching since the pandemicsituation. Theoretically, this research can be used by the next researchers who are interested to make a similar research. The researcher hopes the result of this research gives a positive contribution as solution to solve teaching problem since the outbreak of pandemic.

\section{Research Method}

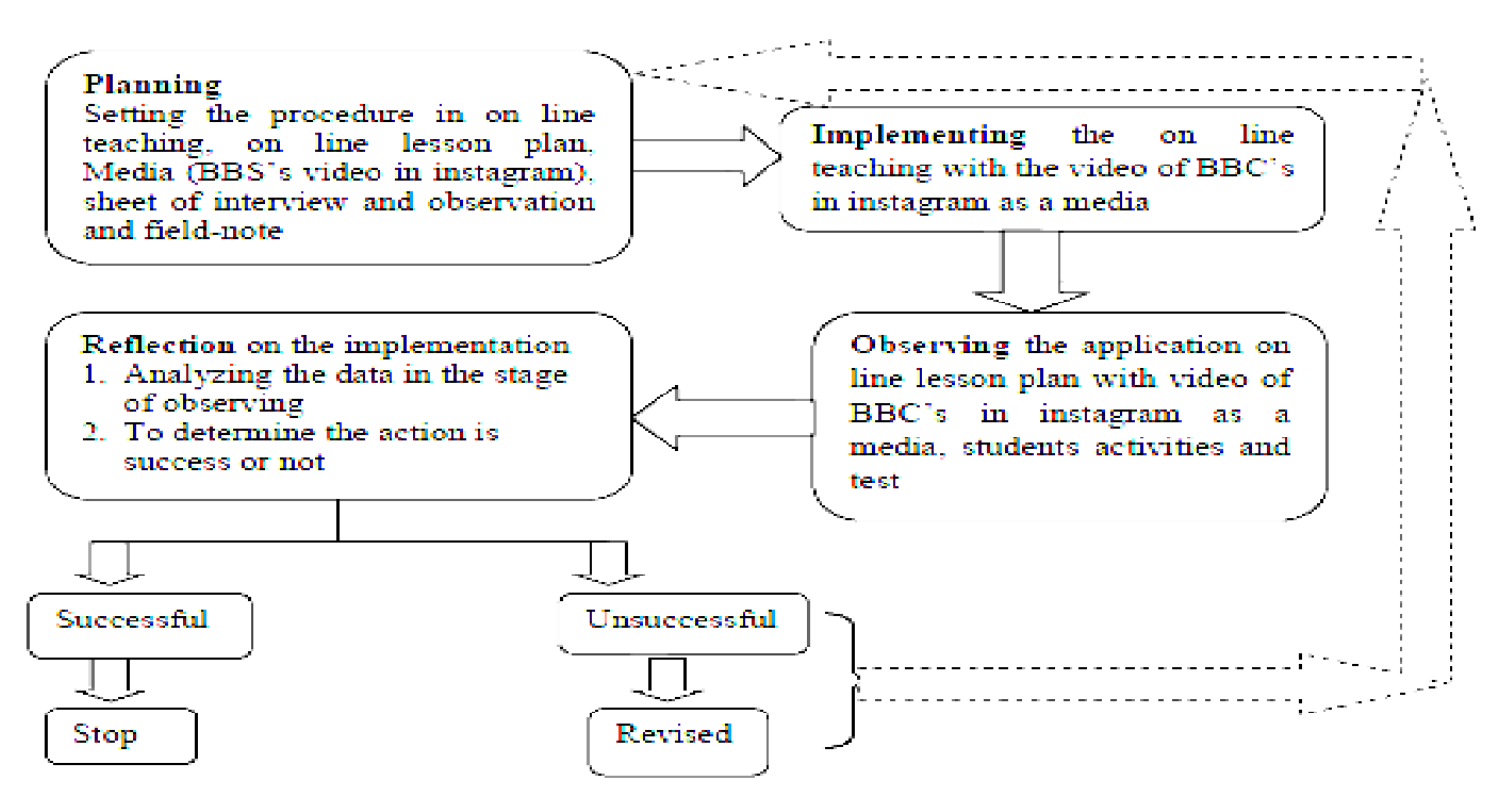

Figure 1. Research Procedure
The design of this research is qualitativequantitative with classroom action research method. Classroom action research typically involves the use of qualitative, interpretive modes of enquiry and data collection by teachers (often with help from academic partners) with a view to teachers making judgments about how to improve their own practices (Kemmis \& McTaggart, 1988). In other words, it is categorized as qualitative since the data of this research is a respond from questionnaire, observation and diary note. In additon to that, this research is categorized as quantitative because the data of this research is a score from the students for each cycle. students at SMP Negeri 3 Medan and the sample of this research are students at grade seven-two. The source of data of this research from students' score, observation sheet, interview sheet and dairy note.

In order to achieve the research objective the researcher followed the research procedure as described in flow chart below.
The population of this research are 
Based on the figure above, Classroom action research is started from planning, implementing, observing and reflection. It is for the first cycle. The cycle categorized success if the average of students above on 75 . In addition to that, it is categorized unsuccessful if the average is lower than KKM. The researcher needs to revise the lesson plan, implementation, observation and reflection to achieve the average higher than KKM.

\section{Result And Discussion}

Video of BBC is an alternative media to use since pandemic covid-19 situation. This media has been implemented through online learning process at SMP Negeri 3 Medan. It seemed that most students are enthusiatic, interested in learning vocabulary. The students' achievement was improved. It can be seen from their average for each cycles.

This research was conducted in three cycle. The researcher investigated the difference, similarities and the cured from the first cycle up to the third cycle. For every cycle, the researcher tried to create a positive atmosphere in teaching vocaburay. Better online teaching atmosphere gave a positive impact. It made the students's achievement in vocabulary better than the previous cycle. The achievement of students can be seen in the following table.

Table 1. Research Finding

\begin{tabular}{lcc}
\hline \multicolumn{1}{c}{ CAR } & $\begin{array}{c}\text { Total } \\
\text { student }\end{array}$ & $\begin{array}{c}\text { The } \\
\text { Average }\end{array}$ \\
\hline Cycle I & 38 & 60,1 \\
\hline Cycle II & 38 & 72,3 \\
\hline Cycle III & 38 & 85,1 \\
\hline \multicolumn{2}{c}{ Table } & above \\
\hline
\end{tabular}

total of students at grade seven-two is 38 . The average of students in the first cycle is 60,1 . It is categorized low since they did not pass the minimum stadard score. The average of students in the second cycle is 72,3 . It is categorized low since they did not pass the minimum stadard score. Finally, the researcher went to the next cycle. The average is 85,1 . It is categorized high since they pass the minimum stadard score.

The data of this research consist of qualitative data and qualitative data. The quantitative data in form of score. The score can be seen in the table one above. It means there was an improvement for each cycle. In addition to that, qualitative data are derived from interview, observation and field note. Based on the qualitative data, it is shown that there is an improvement on respond point of view.

Based on the result of data analysis, the students' problem in learning vocabulary in pandemic covid19 could be improved. The students are able to spell the vocabulary correctly, to know the meaning, and to use vocabulary in appropriate context. In other word, the purpose of this research was achieved. The students can improve their vocabulary mastery even in pandemic covid-19 situation.

Better engagement in the virtual class activities can be achieved through the usage of video BBC's in instagram. It can be as a motivation for the students to improve their mastery on vocabulary. English teacher can make it as an alternative media in teaching English since the policy of social distance.

The research finding above support to the previous study like figure out that instagram significantly affect to the writing recount achievement (Sallamah, Husein, \& Sabiq, 2020). The Instagram as an effective tool for developing learners' vocabulary range and grammatical accuracy (Shazali, Shamsudin, \& Yunus, 2019). There are some advantages to use instagram as a tool or media in teaching descriptive writing (Sirait \& Marlina, 2018). 


\section{Conclusion}

Based on the result of this research, the students' vocabulary mastery can be improved through virtual class activity since the pandemic covid-19. The enthusiatic of students to indicate that virtual class climate improved. However, the researcher even the teacher need to be innovative in redesign virtual lesson plan. This classroom action research proved that video of BBC's in Instagram as a teaching media can improve the students' score in vocabulary mastery. The improvement can be seen from each cycle (table one).

\section{References}

Fatimah, A. S., \& Santiana, S. (2017). Teaching in 21St Century: Stundent-Teachers Perseptions of Technology Use in the Classroom. Scr. J.J Linguist English Teach, 2(1), 125.

Gulati, R., \& al., e. (2020). Education for Primary Care Instagram for Peer teaching: Opportunity and Challenge Instagram for Peer Teaching: Opportunity and Challange ABSTRACT. Educ. Prim. Care, 1-3.

Kamal, A. (t.thn.). Learning English Vocabulary through Instagram.

Kemmis, S., \& McTaggart, R. (1988). The Action Research Planner.

Mozes, G. N. (2020). The Influence of Youtube on English Vocabulary for Children 7-8 Years Old. 119124.

Pangaribuan, T., Sinaga, A., \& Sipayung, K. T. (2017). The Effectiveness of Multimedia Application on Students Listening Comprehension. Englis Lang. Teach, 10(12), 212.

Sallamah, I., Husein, A., \& Sabiq, A. (2020). Does Instagram as Learning Media Affect Student
Writing Skill on Recount Text?: an Experimental Research. 2(3), 129-133.

Sari, F. (2013). Undergraduate Students Perceptions Toward Blended Learning Through Instagram in English for Business Class.

Shazali, S., Shamsudin, Z., \& Yunus, M. (2019). Instagram : A Platform to Develop Student's Writing Ability. Int. J. Acad. Res. Bus. Soc. Sci., 9(1), 88-98.

Sirait, J., \& Marlina, L. (2018). Using Instagram as A Tool for Online Peer-Review Activity in Writing Descriptive Text for Senior High School Students. J. English Lang. Teach, 7(1), 291-302. 